\title{
PENGARUH MODEL QUANTUM TEACHING TERHADAP HASIL BELAJAR SISWA PADA MATERI POKOK LISTRIK DINAMIS
}

\section{Dede Parsaoran Damanik}

Dosen Jurusan Pendidikan Fisika Universitas Darma Agung, Medan

Email : dedeparsaoran@gmail.com

Diterima 23 Juni 2017, disetujui untuk publikasi 28 Agustus 2017

\begin{abstract}
Abstrak Penelitian ini bertujuan untuk mengetahui pengaruh yang signifikan penggunaan model Quantum Teaching tehadap hasil belajar fisika pada materi pokok listrik dinamis. Jenis penelitian yang digunakan dalam penelitian ini adalah quasi eksperimen dengan desain penelitian two group pretes-postes. Populasi dalam penelitian ini adalah seluruh siswa kelas X SMA Kebangsaan Medan T.P. 2016/2017 yang terdiri dari 3 kelas dengan jumah 103 siswa. Pengambilan sampel dilakukan dengan teknik cluster random sampling, dimana siswa kelas X-1 dengan jumlah 33 siswa sebagai kelas eksperimen yang diajar dengan Model Quantum Teaching dan siswa kelas X-2 dengan jumlah 33.siswa yang diajar dengan Model pembelajaran langsung. Hasil penelitian untuk kelas eksperimen dan kelas kontrol menunjukkan bahawa data berdidstribusi normal dan homogen. Untuk uji kesamaan rata-rata pretes didapat memiliki kemampuan awal yang sama, dengan menggunakan uji t dua pihak. Kemudian diberi perlakuan untuk kelas eksperimen yang diajar dengan model Quantum teaching dan di kelas kontrol dengan model pembelajaran langsung dengan hasil nilai rata-rata postes untuk kelas eksperimen diperoleh 72 dengan standar deviasi 9,161 dan nilai rata-rata post-tes untuk kelas kontrol diperoleh 66,424 dengan standar deviasi 8,302. Dari hasil uji $t$ satu pihak dapat disimpulkan ada pengaruh yang signifikan penggunaan model quantum teaching terhadap hasil belajar siswa pada materi pokok listrik dinamis siswa kelas X Semester II SMA Kebangsaan Medan..
\end{abstract}

Kata kunci : Model Quantum Teaching, Hasil Belajar, Listrik

Dinamis 


\section{Pendahuluan}

Pendidikan adalah usaha sadar dan terencana untuk mewujudkan suasana belajar dan proses pembelajaran agar peserta didik secara aktif mengembangkan potensi dirinya untuk memiliki kekuatan spiritual keagamaan, pengendalian diri, akhlak mulia, serta keterampilan yang diperlukan dirinya, masyarakat, bangsa dan Negara. Perkembangan ilmu pengetahuan dan teknologi menuntut adanya sumber daya manusia yang berkualitas yang mampu menghadapi berbagai tantangan dan mampu bersaing. Selain itu, sumber daya yang berkualitas hanya dapat dihasilkan melalui pendidikan yang berkualitas. Pendidikan juga merupakan suatu wadah untuk mengembangkan pengetahuan, keterampilan dan keahlian. Kegiatan proses belajar mengajar di sekolah merupakan usaha dalam meningkatkan kualitas pendidikan nasional, karena sekolah merupakan salah satu perangkat pendidikan. Mengingat fisika merupakan salah satu mata pelajaran yang penting diberbagai jenjang pendidikan, maka sudah sewajarnya mata pelajaran fisika dikembangkan dan diperhatikan oleh.semua pelaku pendidikan.

Fisika merupakan bagian dari ilmu pengetahuan alam (IPA) yaitu suatu ilmu yang mempelajari gejala, peristiwa atau fenomena alam serta mengungkap rahasia hukum semesta. Tujuan dari pembelajaran fisika tersebut akan tercapai jika dalam proses pembelajarannya berjalan dengan baik. Pada kenyataannya, yang terjadi di lapangan masih belum sesuai dengan fungsi dan tujuan yang diharapkan. Data TIMMS (Trend Of International On Mathematics And Science Study) menunjukkan bahwa rata-rata belajar fisika siswa masih rendah dimana prestasi belajar sains siswa Indonesia pada tahun 1999 berada di peringkat ke-32 dengan skor 403, pada tahun 2003 berada di peringkat ke-37 dengan skor 411 dan pada tahun 2007 berada di peringkat ke-35 dengan skor 397. (http://litbang.kemdikbud.go.id/index.php/ti mss). Hasil wawancara yang dilakukan peneliti dengan Ida Kusuma, salah seorang guru fisika di SMA Kebangsaan Medan menunjukkan bahwa hasil belajar fisika siswa masih rendah. Sebagian besar siswa sulit melampaui nilai lulus minimal KKM. Sehingga, untuk mencapai nilai lulus minimal KKM tersebut, guru harus mengadakan remedial ataupun ujian ulangan kepada siswa. Rendahnya hasil belajar siswa khususnya pada mata pelajaran Fisika disebabkan karena penyajian fisika yang kurang menarik dan terkesan sulit sehingga siswa merasa tidak siap untuk mempelajarinya. Hal ini juga menyebabkan kurangnya minat siswa terhadap mata pelajaran fisika. Fathurrohman (2015) mengatakan bahwa "jika dalam istilah mengajar (pengajaran) atau teaching menempatkan guru sebagai pemeran utama memberikan informasi, maka dalam instruction guru lebih banyak berperan sebagai fasilitator, memanajemen berbagai sumber dan fasilitas untuk dipelajari peserta didik". Dalam hal ini, guru belum menerapkan model pembelajaran yang bervariasi karena pembelajaran hanya berpusat kepada guru. Dengan kata lain, pola mengajar yang digunakan guru adalah pengajaran langsung, sehingga menyebabkan siswa kurang aktif dalam pembelajaran. Upaya-upaya yang dapat dilakukan untuk mengatasi permasalahan-permasalahan tersebut perlu dikembangkan model pembelajaran yang dapat meningkatkan hasil belajar siswa melalui cara belajar yang aktif serta mengubah keadaan dan motivasi dengan TANDUR (Tumbuhkan, Alami, Namai, Demonstrasikan, Ulangi dan Rayakan). Salah satu model pembelajaran yang sesuai dengan kebutuhan di atas adalah model Quantum Teaching. Bobbi Deporter (2010) memberikan definisi Quantum Teaching, yaitu Quantum adalah interaksi yang mengubah energi menjadi cahaya. Dengan demikian, Quantum Teaching adalah penggubahan bermacam-macam interaksi yang ada di dalam dan di sekitar momen belajar. Interaksi-interaksi ini mencakup unsur-unsur untuk belajar efektif yang 
mempengaruhi kesuksesan siswa. Interaksiinteraksi ini mengubah kemampuan dan bakat alamiah siswa menjadi cahaya yang akan bermanfaat bagi mereka sendiri dan bagi orang lain. Penelitian tentang model Quantum Teaching telah dilakukan oleh Mohamad Solikin (2014) yang menyatakan bahwa Quantum Teaching berpengaruh positif terhadap hasil belajar siswa pada pokok bahasan Hukum Newton di kelas X SMA Wahid Hasyim 4 Sidoarjo. Menurut Renni (2014) yang menyatakan bahwa sebagian besar penggunaan pembelajaran Quantum Teaching dengan pendekatan multi kecerdasan sudah terlaksana dengan baik. Hasil observasi awal yang dilakukan peneliti di SMA Kebangsaan Medan menunjukkan bahwa di sekolah tersebut memiliki sarana dan prasarana yang mendukung proses pembelajaran dengan model Quantum Teaching, sehingga penelitian ini dapat dilaksanakan di sekolah tersebut. Penelitian ini bertujuan untuk mengetahui pengaruh yang signifikan penggunaan Model Quantum Teaching terhadap hasil belajar fisika pada Materi Pokok Listrik Dinamis.

\section{Metode Penelitian}

Penelitian ini adalah penelitian quasi eksperimen. Populasi penelitian ini adalah seluruh siswa kelas $X$ SMA yang terdiri dari 3 kelas. Sampel penelitian dilakukan dengan cara tehnik acak kelas (cluster random sampling) sebanyak dua kelas. Dimana kelas pertama dijadikan kelas eksperimen (kelas X1) dengan menggunakan model Quantum Teaching dan kelas kedua dijadikan kelas kontrol (kelas X-2) dengan model pembelajaran Langsung. Jumlah siswa masing-masing tiap kelas 33 orang.

Peneliti melakukan tes untuk mengetahui hasil belajar fisika siswa pada kedua kelas sebelum dan sesudah diberikan perlakuan. Desain penelitian yang digunakan desain two group pretest-posttest design.
Data yang diperoleh ditabulasikan kemudian dicari rata-ratanya. Sebelum dilakukan analisis data, terlebih dahulu ditentukan nilai masing-masing kelompok sampel lalu dilakukan pengolahan data dengan langkah-langkah sebagai berikut yakni : menghitung nilai rata-rata dan simpangan baku, uji normalitas menggunakan uji Lilliefors, uji homogenitas menggunakan uji $\mathrm{F}$, pengujian kesamaan ratarata pretes menggunakan uji t dua pihak dan pengujian hipotesis menggunakan uji $t$ satu pihak pada data postes.

\section{Hasil Penelitian dan Pembahasan}

Sebelum dilakukan perlakuan pada penelitian terlebih dahulu diberikan tes pendahuluan untuk mengetahui kemampuan awal siswa pada kedua kelompok sampel diperoleh nilai rata-rata pretes siswa di kelas eksperimen 38,909 dengan standar deviasi 9,125 dan varians 83,271. Sedangkan nilai rata-rata pretes di kelas kontrol 37,333 dengan standar deviasi 8,925 dan varians 79,666. Peneliti memberikan perlakuan yang berbeda dimana pada kelas kontrol menggunakan model direct instruction dan kelas eksperimen menggunakan model quantum teaching. Dari tabel diatas, diperoleh nilai rata-rata postes di kelas eksperimen 72 dengan standar deviasi 9,161 dan varians 83,999. Sedangkan nilai rata-rata postes di kelas kontrol 66,424 dengan standar deviasi 8,302 dan varians 68,938 . Hasil pretes kedua kelas dapat dilihat pada Gambar 1 sebagai berikut. 


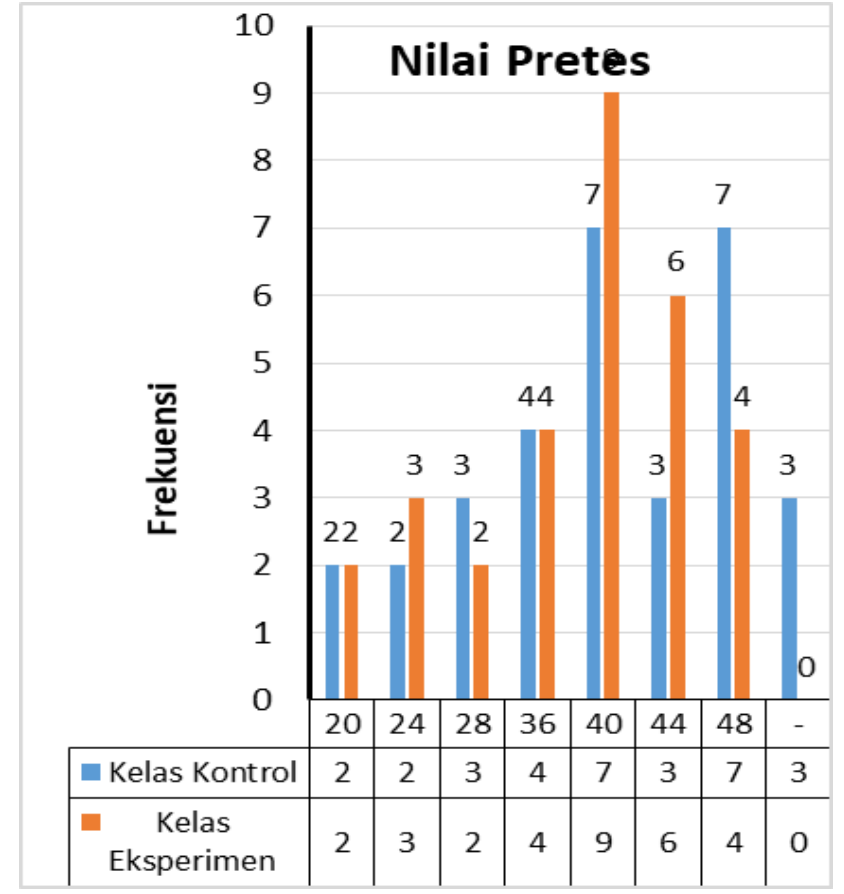

Gambar 1. Diagram Batang Data Nilai Pretes

Hasil postes kedua kelas dapat dilihat pada Gambar 2 sebagai berikut.

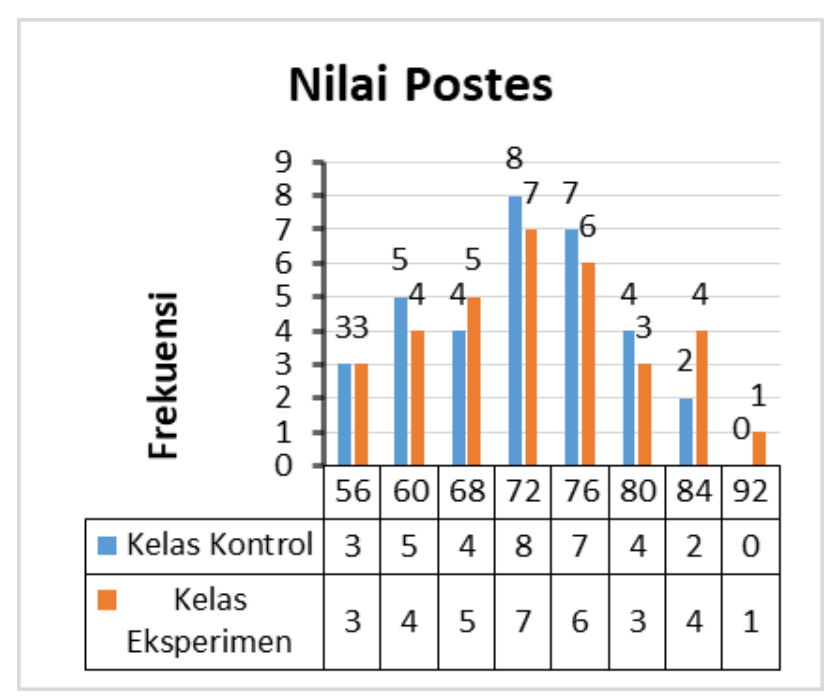

Gambar 2. Diagram Batang Data Postes Kelas Eksperimen dan Kelas Kontrol.

Uji normalitas dengan uji Lilliefors dengan kriteria Lo $<$ Ltabel dengan $\alpha=0,05$ dapat diartikan data berdistribusi normal. Berdasarkan hasil uji normalitas dengan uji Lilliefors untuk pretes kelas eksperimen pada $\alpha=0,05$ dengan $\mathrm{N}=33$ diperoleh Ltabel $=0,15$ dan Lhitung $=0,099$. Karena Lhitung $(0,099)<$ Ltabel $(0,15)$, maka nilai hasil belajar pretes kelas eksperimen berdistribusi normal. Pada pretes kelas kontrol pada $\alpha=0,05$ dengan $\mathrm{N}=33$ diperoleh Ltabel $=0,15$ dan Lhitung $=0,101$. Karena Lhitung $(0,101)<$ Ltabel $(0,15)$, maka nilai hasil belajar pretes kelas kontrol berdistribusi normal. Syarat normalitas untuk postes kelas eksperimen yang diajar dengan model quantum teaching pada $\alpha=0,05$ dengan $\mathrm{N}=33$ diperoleh $\mathrm{L}_{\text {tabel }}=0,15$ dan Lhitung $=0,115$. Karena Lhitung $(0,115)<$ Ltabel $(0,15)$, maka nilai hasil belajar postes yang diajar dengan model quantum teaching berdistribusi normal. Post tes kelas kontrol yang diajar dengan model direct instruction pada $\alpha=0,05$ dengan $\mathrm{N}=$ 33 diperoleh $\mathrm{L}_{\text {tabel }}=0,15$ dan Lhitung $=0,136$. Karena Lhitung $(0,137)<$ Ltabel $(0,15)$, maka nilai hasil belajar postes yang diajar dengan model direct instruction berdistribusi normal.

Uji homogenitas untuk pretes kelas eksperimen dan kelas kontrol pada $\alpha=$ 0,10 dengan $\mathrm{N}=33$ diperoleh $\mathrm{F}_{\text {tabel }}=1,82$ dan $F_{\text {hitung }}=1,045$. Karena F Fitung $(1,045)<$ Ftabel $(1,82)$, maka dapat disimpulkan bahwa data tersebut homogen.

Uji homogenitas untuk postes kelas eksperimen dan kelas kontrol pada $\alpha=$ 0,10 dengan $\mathrm{N}=33$ diperoleh $\mathrm{F}_{\text {tabel }}=1,82$ dan $F_{\text {hitung }}=1,218$. Karena F Fitung $(1,045)<$ Ftabel (1,82), maka dapat disimpulkan bahwa data tersebut homogen, sehingga data tersebut telah memenuhi persyaratan untuk dilakukan pengujian hipotesis penelitian.

Setelah data normal dan homogen maka dapat dilakukan uji kesamaan ratarata menggunakan uji $t$ dua pihak. 
Berdasarkan hasil uji t dua pihak didapat bahwa kemampuan awal kedua kelas adalah sama. Peneliti memberikan perlakuan yang berbeda di mana pada kelas eksperimen diberikan pembelajaran dengan menggunakan model Quantum teaching sedangkan pada kelas kontrol diberikan model pembelajaran Direct Intruction.

Uji hipotesis untuk pretes kelas eksperimen dan kelas kontrol diperoleh thitung $=0,728$ dan tabel $=1,99$. Karena thitung $<$ tabel, maka dapat disimpulkan bahwa kemampuan awal kedua kelas sampel adalah sama.

Uji hipotesis untuk postes kelas eksperimen dan kelas kontrol diperoleh tabel $=1,669$ dan thitung $=2,657$. Karena thitung>ttabel, maka dapat disimpulkan $\mathrm{H}_{a}$ diterima yang berarti bahwa ada pengaruh yang signifikan model Quantum Teaching terhadap hasil belajar fisika pada materi pokok listrik dinamis.

Hasil penelitian menunjukkan bahwa ada pengaruh yang signifikan penggunaan model Quantum Teaching terhadap hasil belajar fisika pada materi pokok listrik dinamis. Kelompok sampel yang diajar dengan Model Quantum Teaching memperoleh hasil belajar yang lebih tinggi dibandingkan dengan kelompok siswa yang diajar dengan menggunakan Model Direct Instruction. Hal ini terjadi karena kegiatan belajarmengajar dengan Model Quantum teaching adalah suatu model yang mengubah suasana belajar yang menyenangkan sehingga meningkatkan keaktifan siswa dalam proses belajar-mengajar. Siswa mengikuti langkah-langkah pembelajaran ini dengan TANDUR (Tumbuhkan, Alami, Namai, Demonstrasikan, Ulangi dan Rayakan), pada tumbuhkan, siswa termotivasi untuk mengetahui apa yang akan dipelajari dan langsung mengalami gejala atau fenomena yang diberikan guru tentang topik yang dipelajari. Pada saat penamaan, siswa diajak untuk memberi respon tentang nama yang dipelajari dan diulang sehingga mereka hafal tentang materi yang diajarkan, lalu didemonstrasikan sehingga mereka dapat melihat proses dan gejala yang terjadi, dan terakhir dirayakan keberhasilan yang mereka peroleh, sehingga mereka merasa dihargai dan percaya diri.

Selama penelitian di lapangan, ada kelebihan-kelebihan yang peneliti temukan selama pembelajaran menggunakan model Quantum Teaching pada materi pokok listrik dinamis. Adapun kelebihannya adalah siswa dapat mengamati serta melakukan demonstrasi sendiri sehingga siswa lebih mudah mengerti dan memahami materi pelajaran yang disampaikan karena terlibat aktif dalam pembelajaran.

\section{Simpulan dan Saran}

Berdasarkan hasil penelitian dan pembahasan, Hasil belajar siswa yang diajar dengan Model Quantum Teaching pada materi pokok listrik dinamis memiliki nilai rata-rata $=72$. Hasil belajar siswa yang diajar dengan Model Direct Instruction pada materi pokok listrik dinamis memiliki nilai rata-rata $=$ 66,424 .

Ada pengaruh yang signifikan penggunaan model Quantum Teaching terhadap hasil belajar fisika pada materi pokok listrik dinamis terlihat dari thitung $>$ tabel dimana thitung $=2,657$ dan tabel $=1,669$ pada taraf signifikan $\alpha=0,05$ dengan $\mathrm{dk}=64$. Bagi guru, khususnya guru fisika yang juga diharapkan untuk menggunakan model 
pembelajaran yang menyenangkan dan dapat melibatkan keaktifan siswa dalam belajar, salah satunya dengan menerapkan model Quantum Teaching.

Bagi peneliti selanjutnya yang ingin meneliti model Quantum Teaching disarankan melakukan penelitian pada lokasi dan materi yang berbeda serta terlebih dahulu memperhatikan kelemahan-kelemahan dalam penelitian ini untuk dapat mencapai peningkatan hasil belajar yang lebih baik.

\section{Daftar Pustaka}

Arikunto, S., 2012, Dasar - dasar Evaluasi Pendidikan, Jakarta: Bumi Aksara.

Deporter Bobbi, dkk ., 2010, Quantum Teaching, Bandung : Kaifa.

Dimyati. 2013, Belajar dan Pembelajaran, Jakarta : Jineka Cipta.

Fathurrohman, Muhammad., 2015, ModelModel Pembelajaran Inovatif, Yogjakarta, Ar-Ruzz Media.

http://litbang.kemdikbud.go.id/index.php/tim ss

Jihad, Asep., 2013, Evaluasi Pembelajaran, Yogyakarta : Multi Pressindo.

Kanginan, M., 2007, Fiska untuk SMA/MA Kelas X, Jakarta: Erlangga.

Muhibbinsyah.2010, Psikologi Pendidikan, Bandung : Remaja Rosdakarya.
Purwoko \& Fendri., 2010, Fisika 1 SMA kelas X, Jakarta: Yudhistira.

Renni, 2014, Pengaruh Model Pembelajaran Quantum Teaching terhadap Hasil Belajar Siswa pada Pokok Bahasan Hukum Newton di Kelas X SMA Wahid Hasyim 4 Sidoarjo. Skripsi Pendidikan Fisika Universitas Darma Agung Medan.

Rusman. 2011, Model-Model Pembelajaran: Mengembangkan Profesionalisme Guru, Jakarta: Rajawali Pers.

Shoimin Aris., 2014, 68 Model Pembelajaran Inovatif dalam Kurikulum 2013. Yogyakarta : Ar-Ruzz Media.

Slameto. 2010, Belajar dan Faktor - Faktor Yang Mempengaruhi, Jakarta: Rineka Cipta.

Solikin, Mohamad., 2014, Pengaruh Model Pembelajaran Quantum Teaching terhadap Hasil Belajar Siswa Pada Materi Pokok Fluida Statis di SMA Swasta Raksana Medan.Skripsi Pendidikan Fisika Universitas Darma Agung Medan.

Sudjana. 2012, Metoda Statistika, Bandung: Tarsito.

Sugiyono. 2010, Metode Penelitian Kuantitatif Kualitatif dan $R \& D$, Bandung: Alfabeta.

Trianto.2010, Mendesain Model Pembelajaran Inovatif - Progresif, Jakarta: Kencana. 